\title{
CIÊNCIANATURA
}

\section{Spray drying of the buriti pulp at different maltodextrin concentrations and temperature}

\author{
Wolia Costa Gomes ${ }^{1}$, Rossana Maria Feitosa de Figueirêdo ${ }^{2}$, Alessandre José de Melo Queiroz ${ }^{3}$, \\ Alyson da Luz Pereira Rodrigues ${ }^{4}$, Glauber Cruz $^{5}$ and Paulo Cesar Mendes Villis ${ }^{6}$ \\ ${ }^{1}$ Ceuma University - Masters in Environmental, São Luís - MA, Brazil \\ ${ }^{2}$ Federal University of Campina Grande, Campina Grande - PB, Brazil \\ ${ }^{3}$ Federal University of Campina Grande, Campina Grande - PB, Brazil \\ ${ }^{4}$ Ceuma University - Masters in Environmental, São Luís - MA, Brazil \\ ${ }^{5}$ Federal University of Maranhão - Department of Mechanical Engineering, São Luís - MA, Brazil \\ ${ }^{6}$ Ceuma University - Masters in Environmental, São Luís - MA, Brazil
}

\begin{abstract}
In this work, the formulations prepared with buriti pulp and different maltodextrin concentrations (5, 10 and $15 \%$ ) were dried in spray dryer and the chemical, physical and physical-chemical characteristics of the formulations and powder samples were evaluated. In this drying process two kinds of powder samples were collected: one into drying chamber and another in the cyclone. Using a factorial experimental planning, the experiments were conducted, in order to assess the moisture and ash contents, total acidity and density of both samples. The formulations dried in the spray dryer presented to be feasible for the production of buriti pulp powder; however, powder samples collected into drying chamber and cyclone were different. Among the parameters analyzed, it was found that only for density the samples collected into drying chamber, that the first-order empirical model obtained was statistically significant and predictive.
\end{abstract}

Keywords: Mauritia flexuosa; Spray drying; Maltodextrin; Experimental design 


\section{Introduction}

Buritizeiro, i.e., tree that produce the buriti (Mauritia flexuosa), is a native species found in the Amazon region up to the Cerrados of some Brazilian States, mainly in the Eastern and West regions, and along the Brazilian coast, also reaching countries as Bolivia, Colombia, Ecuador and Peru (Donadio et al., 2004). It has great commercial value, although its nutritional and functional properties are still few known (Milanez et al., 2018). It is considered as the largest natural reserve of pro-vitamin A and an excellent source of oleic acid, pulp lipid fraction, being basically composed of tocopherol, carotenoids and oils (CARVALHO; ORLANDA, 2017).

The buriti fruit, due all these characteristics can be used for the several products production, such as pulp, jams, jellies, ice cream, nectars, dyes, antioxidants and pulp flour, which can be introduced into Brazilian food habits to prevent or minimize the incidence of certain diseases with reduced cost, due to the large production of this fruit (MANHÃES, 2007; PINTO et al., 2012; DUARTE, 2011).

The fruit buriti present an elliptical and oval shape, surrounded by a pericarp (or husk), and composed of reddish-brown triangular scales. The mesocarp (pulp or mass) is thin, yellowish or orange, fleshy and oily. The pulp has a pH around 4.7 and is 20 times richer in vitamin A than carrot, which is a food considered the higher source of this vitamin (KOOLEN et al., 2013). Their endocarp (or bush) is formed by a spongy tissue, thin, white to yellowish, with high cellulose content, which present low density and allows the fruit to float when immersed in water. The endosperm or seed is harder, ovoid shape, with an average of $2.5 \mathrm{~cm}$ diameter, occupying most of fruit volume (SAMPAIO, 2012).

The several drying processes of the vegetable origin products can be classified at 2 (two) groups: natural drying or to the sun and artificial drying or dehydration, for example, spray-drying, jetting, greenhouses, foam layer, lyophilization, which are widely used for drying heat-sensitive foods, transforming them into powder (BEZERRA et al., 2015). Although these were developed to promote rapid drying of liquid foods, such as juices, it has been widely used for pasty foods, for example, purees and fruit pulps (BAG et al., 2011).

Among methods of food preservation, drying is one of the post-harvest technologies, widely used to overcome problems related to overproduction, oversupply and high perishability of fruits and vegetables (CHONG; LAW, 2011). Several innovative food processing techniques are found in the literature, such as: microwave, ultrasound, electric pulse field, instantaneously controlled pressure drop, supercritical fluid processing (CHEMAT et al., 2017).

Drying is an important process parameter for preservation of food components and it is widely applicable in food sectors (RAY; RAYCHAUDHURI; CHAKRABORTY, 2016). Studies such as the combination of drying methods (free convection, forced convection) prove a significant preservation of phytochemical content compared to traditional methods (NISTOR et al., 2017).

According to Murugesan and Orsat (2011), spray drying is one best drying methods, which convert directly fluid materials into solid or semi-solid particles; consequently, decrease and particles dispersion contained into drying gases, exponentially increase the surface area, helping to dry feed fluid in seconds, through of the uniform heat transfer and mass during the process. The use principle of such equipment consists in transforming the product in fluid state in a dry particle in the powder form (SHISHIR; CHEN, 2017; ZOTARELLI et al., 2017). The obtained material present the maximum initial characteristics of the original product and protect it from the adverse conditions of the external environment; for this purpose, additives with varying proportions are incorporated into the product to be dried to suit the process (RAY et al., 2016; VINCENZETTI et al.,2018).

In this context, this research evaluated the drying different formulations carried out with buriti pulp and maltodextrin concentrations in a spray dryer, to assess the input variables influence, such as drying temperature and maltodextrin concentrations on the responses of moisture content, ash, titratable total acidity and density of the powder samples.

\section{Material and Methods}

The raw material used in this study was buriti pulp (Mauritia flexuosa, L. f.), from Codó municipality (Maranhão State). Emulsions (formulated pulps) containing equal parts of buriti pulp and distilled water (1:1), and addition of three maltodextrin concentrations $\left(5,10\right.$ and 15\%) provided by Mor Rex ${ }^{\circledR}$, with equivalent dextrose equal to 10 (ED $\left.=10\right)$. These emulsions or formulations were homogenized in a blender and dried in a spray dryer, model LM MSD 1.0 - Labmaq, Brazil. The dryer was operated at 130,150 and $170{ }^{\circ} \mathrm{C}$ drying air temperatures (input) by mean a pneumatic nozzle with 1.2 mm diameter, emulsion pumping rate was $0.5 \mathrm{~L} \mathrm{~h}^{-1}$ and compressed air flow rate of $0.03 \mathrm{~L} \mathrm{~h}^{-1}$. The obtained powder samples collected into drying chamber and in dryer cyclone were characterized as moisture, total titratable acidity, density and ashes.

For the experiments execution, a factorial design $2^{2}$ with two central points (level 0) was used and two input variables, drying temperature and maltodextrin concentrations were specified, wich influence on the responses. In order to verify the variables influence on the responses for the moisture and ash contents, total titratable acidity and density, a factorial experimental design $2^{2}$ was elaborated, consisting of four distinct experiments and two central points, as shown in the planning matrix presented in Table 1. 
Table 1. Factorial planning matrix $2^{2}+2$ in the center point for the formulation (buriti pulp/water + maltodextrin concentrations at 5,10 and $15 \%)$

\begin{tabular}{ccc}
\hline $\begin{array}{c}\text { Experiment } \\
\text { (number) }\end{array}$ & Drying temperature $\left({ }^{\circ} \mathrm{C}\right)$ & Maltodextrin concentration (\%) \\
\hline $\mathbf{1}$ & $-1(130)$ & $-1(5)$ \\
$\mathbf{2}$ & $+1(170)$ & $-1(5)$ \\
$\mathbf{3}$ & $-1(130)$ & $+1(15)$ \\
$\mathbf{4}$ & $+1(170)$ & $+1(15)$ \\
$\mathbf{5}$ & $0(150)$ & $0(10)$ \\
$\mathbf{6}$ & $0(150)$ & $0(10)$ \\
\hline
\end{tabular}

\section{Results and discussion}

The moisture of the powder samples collected into drying chamber (Ca) varied from 3.84 to $5.22 \%$ and in the cyclone (Ci) between 2.56 and 5.86\%. PENA et al. (2008) found for açai powder dried in spray dryer, moisture of 3.1\%, at the same values range of the powder samples evaluated in this work. CARVALHO et al. (2017) found for umbu-cajá with goat milk powder, higher moisture, ranging from 5.17 to $7.54 \%$ in to chamber and in the cyclone, 2.77 and $6.40 \%$. The moisture of the samples collected in the cyclone was lower than the samples collected into chamber, except for the number experiment 2 . A hypothesis for this behavior can be that, during drying, the larger droplets are dried and fall into chamber, while others may breakdown, reducing their size and consequently, become drier (lower moisture); hence, smaller particles are drawn for cyclone.

With the data obtained from moisture contents of the powder samples collected into chamber and in cyclone, linear regressions presented in Eqs. 1 were performed as drying temperature function $\left({ }^{\circ} \mathrm{C}\right)$, maltodextrin concentration $(\%)$ and interaction between these two parameters. The equations are statistically significant at $95 \%$ confidence. It was verified for the collected samples into chamber (Equation 1), that only the mean and interaction between the two parameters evaluated were significant, however, for the collected samples in cyclone (Equation 2), the mean, air drying temperature and interaction between temperature and maltodextrin concentration were significant.

Moisture $(\mathrm{Ca})=4.58+0.14 \mathrm{~T}+0.12 \mathrm{C}-0.55 \mathrm{~T} . \mathrm{C}$

Moisture $(\mathrm{Ci})=3.85+1.10 \mathrm{~T}-0.26 \mathrm{C}-0.54 \mathrm{~T} . \mathrm{C}$

Where, $\mathrm{T}$ is the drying temperature $\left({ }^{\circ} \mathrm{C}\right)$ and $\mathrm{C}$, the maltodextrin concentration $(\%)$

It was observed from variance analysis of the moisture of the collected powder samples into chamber, that $\mathrm{F}_{\text {calculated }}$ value (17.14) was lower than the $\mathrm{F}_{\text {tabulated }}$ value (19.16) for $95 \%$ confidence level and determination coefficient (R2) was 0.9625. According to the F-test, first-order moisture model for the sample collected in the drying chamber (Ca) was not statistically significant (RODRIGUES; LEMMA, 2009).

The $\mathrm{Fc}_{\text {alculated }}$ value (41.76) was approximately 2.2 times greater than the $\mathrm{F}_{\text {tabulated }}$ value (19.16), meaning that the first order model for moisture powder the collected in cyclone is statistically significant at $95 \%$ confidence, but is not predictive, with the $\mathrm{R}^{2}$ obtained of 0.9843 . A linear regression can be significant of the F-test view point, but can not be useful for making predictions, because covers a small range of the factors studied (RODRIGUES; LEMMA, 2009). For a linear regression not be only statistically significant, but also useful for the predictive purposes, F0 metric value should be at least four to five times the $\mathrm{F} \alpha,(\mathrm{p}-1),(\mathrm{N}-\mathrm{p})$ value, i.e., the $\mathrm{F}_{\text {calculated }}$ and $\mathrm{F}_{\text {tabulated }}$ ratio, should be higher to 4 (DUARTE; MEOLA, 2007).

Response surfaces, representing the drying temperature effects and maltodextrin concentrations on the physical-chemical parameters of the collected powder samples into chamber and in cyclone, were analyzed when order first models were statistically significant at $95 \%$, because no presents none importance when there is no significance. For this reason, response surfaces for the variables maltodextrin concentration and drying temperature for the moisture of the collected powder samples in dryer chamber were not presented. Figure 1(a) shows the response surfaces for the variables maltodextrin concentration and air drying temperature for the moisture of the collected powder samples into dryer chamber and cyclone. 
Figure 1 - Influence of the drying temperatures and maltodextrin concentrations on the contents: (a) moisture - cyclone;

(b) ash - cyclone; (c) titratable total acidity - chamber; (d) titratable total acidity - cyclone and (e) density - chamber.

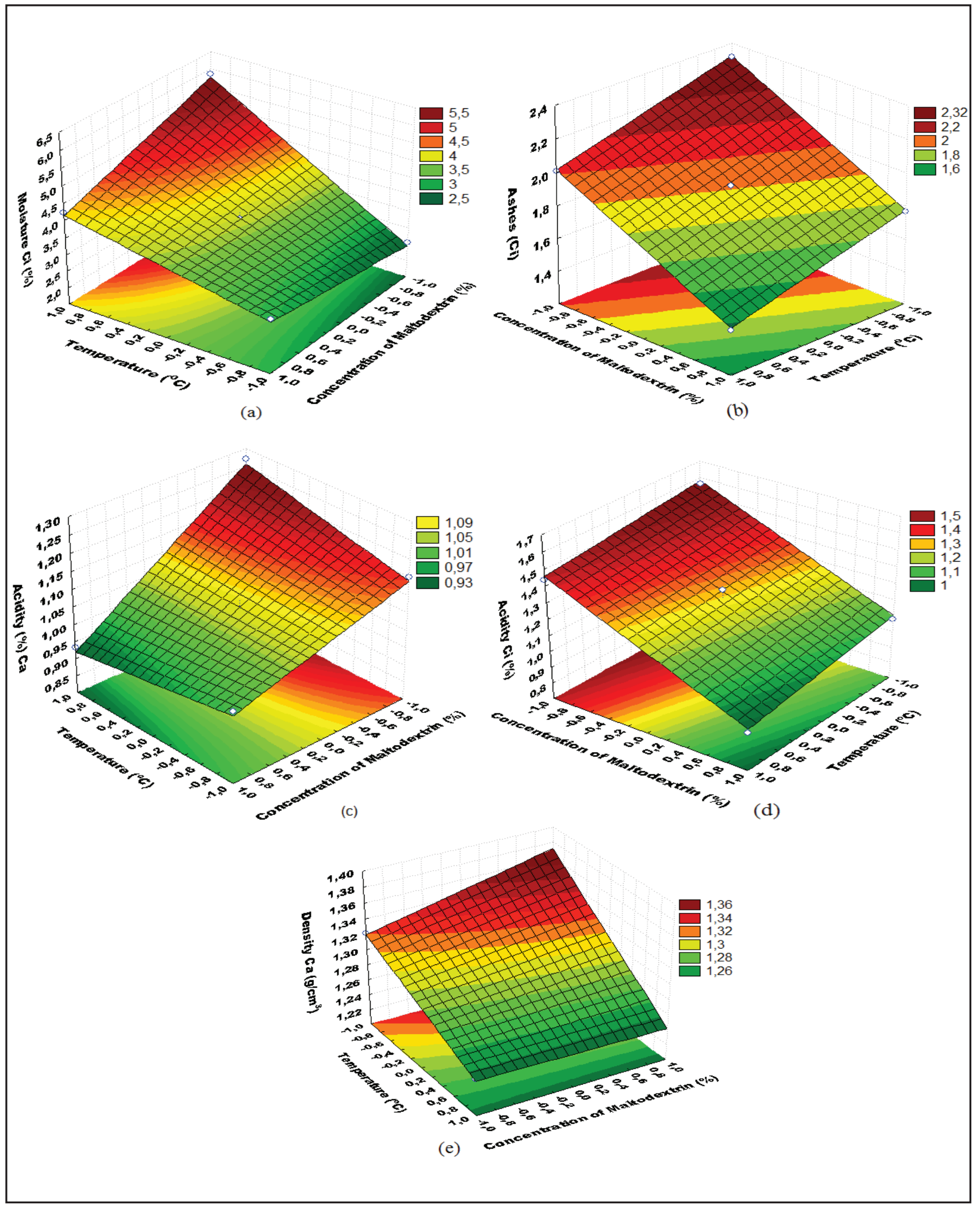


It was verified that the drying air temperature showed an increasing effect on the response surface, i.e., when this go from level -1 to +1 , moisture powder collected in the cyclone increases. For setting the temperature variable to the lower level -0.2 , moisture is around 2.5 and $3 \%$, for any range maltodextrin concentration. For the collected samples in the cyclone, lower moisture $(2.56 \%)$ was obtained for the dried sample with lower maltodextrin concentration (5\%) and drying temperature of 130 ${ }^{\circ} \mathrm{C}$. A probable explanation for such situation is that drying at the lower temperature takes longer than in other temperatures, and dry sample is maintained in the cyclone by longer time and, consequently, more dehydrated than at higher temperatures where process is faster (NUNES et al., 2015)

The ashes of the collected samples in the chamber varied between 1.34 and $2.33 \%$ and in the cyclone from 1.47 to $2.33 \%$, such values were close of the determined values by COSTA et al. (2009) for the artichoke dried powder in a spray dryer, i.e., $2.02 \%$, and higher than that the determined value by SOUZA et al. (2015) for the powder athemoya pulp sample, which was $0.97 \%$ into dryer chamber and $0.74 \%$ in cyclone.

The linear regression equations (Eqs. 3 and 4) for the experimental data adjusted, regarding drying air temperature $\left({ }^{\circ} \mathrm{C}\right)$ and maltodextrin concentration (\%) of the emulsions produced, allowed select the combination of maximized levels for obtaining the best response for each situation. For powder samples collected in the spray dryer chamber, only the observed values average showed a significant effect; however for the samples collected in the cyclone the average drying air temperature and maltodextrin concentration had a significant effect.

$$
\begin{aligned}
& \text { Ash }(\mathrm{Ca})=1.85-0.21 \mathrm{~T}-0.28 \mathrm{C}+0.08 \mathrm{~T} . \mathrm{C} \\
& \text { Ash }(\mathrm{Ci})=1.9-0.15 \mathrm{~T}-0.27 \mathrm{C}+0.004 \mathrm{~T} . \mathrm{C}
\end{aligned}
$$

From variance analysis adjusted for the first order model with 4 parameters for the ash samples collected in the chamber, was verified that $\mathrm{F}_{\text {calculated }}$ value (2.93) was lower than $\mathrm{F}_{\text {tabulated }}$ value (19.16), for a 95\% confidence level and $\mathrm{R}^{2}$ value was 0.8147 . Therefore, according to F-test, can be affirmed that empirical model is not statistically significant.

In ANOVA case, for the ashes of powder samples collected in the cyclone, was verified that $\mathrm{F}_{\text {calculated }}$ value (182.0) was higher than $\mathrm{F}_{\text {tabulated }}$ value (19.16), and a ratio between the values of approximately 9.5 times, with $\mathrm{R}^{2}$ adjusted for model of 0.9963; which can be affirmed according to F-test that empirical model is statistically significant and predictive, according to Duarte; Meola (2007).

Figure 1(b) shows the effects of the input variables, such as maltodextrin concentration and drying air temperature on the ash content of the samples collected in the cyclone. It is verified that drying temperature and maltodextrin concentration present decreasing influences, i.e, when these pass from level -1 to level +1 , was observed that ash content decreased for $2.31 \%$, when the drying temperature was $130{ }^{\circ} \mathrm{C}(-1)$ and maltodextrin concentration of $5 \%(-1)$.

The titratable total acidity (TTA) of the powder samples ranged from 0.93 to 1.27 for the samples collected in the dryer chamber and from 0.93 to 1.56 for the samples in the cyclone. Higher contents were found by CARVALHO et al. (2017) for the $u m b u$-cajá with goat milk powder samples, obtained by drying process in a spray dryer, whose ATT values were from 3.92 to $5.76 \%$ in the chamber, and from 3.84 to 5.90 for the cyclone, respectively. Lower ATT values were obtained for the samples with higher maltodextrin concentration and higher values for the samples with lower amount of maltodextrin, demonstrating the influence of this parameter on the ATT.

The ATT values of the samples collected in the chamber were, in all experiments, lower than samples collected in the cyclone, indicating that samples collected in the chamber were less acidic. A probable explanation for this effect can be the exposure of the samples to higher temperatures in the drying chamber and a longer exposure time under this condition, when compared to the samples collected in the cyclone, providing greater organic acids oxidation in the drying chamber (reference). Equations 5 and 6 represent the coded empirical models of linear regressions adjusted to the experimental data of the total titratable acidity for the powder samples collected in the chamber and cyclone, respectively. In these equations, the parameters in bold are statistically significant at the $95 \%$ level of confidence, because only the average and maltodextrin concentration significantly influenced the ATT of the powder samples.

$$
\begin{aligned}
& \text { Acidity }(\mathrm{Ca})=1.08+0.01 \mathrm{~T}-0.12 \mathrm{C}-0.05 \mathrm{~T} . \mathrm{C} \\
& \text { Acidity }(\mathrm{Ci})=1.27-0.07 \mathrm{~T}-0.25 \mathrm{C}-0.004 \mathrm{~T} . \mathrm{C}
\end{aligned}
$$

From variance analysis of the models fitted to the experimental data for the total titratable acidity of the powder samples collected in the chamber was verified that $\mathrm{F}_{\text {calculated }}$ value (25.22) was higher than $\mathrm{F}_{\text {tabulated }}$ value (19.16) for ATT, first model was considered statistically significant for the $95 \%$ confidence level. The ratio between $\mathrm{F}_{\text {calculated }}$ and $\mathrm{F}_{\text {tabulated }}$ was approximately 1.3 and considered not predictive. The $\mathrm{R}^{2}$ value observed for the adjusted model was 0.9738 . The $\mathrm{F}_{\text {calculated }}$ value (31.82) was higher than $\mathrm{F}_{\text {tabulated }}$ value (19.16) for ATT of the powder samples collected in the cyclone, and model was considered statistically significant at $95 \%$ confidence level and ratio between $\mathrm{F}_{\text {calculated }}$ and $\mathrm{F}_{\text {tabulated }}$ was approximately 1.7 and also considered 
non-predictive (DUARTE; MEOLA, 2007). The $\mathrm{R}^{2}$ value of the model adjusted for ATT was 0.9793.

Figure 1 shows the ATT representation as function of the drying temperature and maltodextrin concentration of the collected powder samples in chamber (c) and cyclone (d). The averages and maltodextrin concentration presented significant influences. It can be seen in Figure 1(c) that for any temperature value, ATT increases with decreasing maltodextrin concentration, i.e., althout that maltodextrin has a small acidity is not sufficient for the highest concentration level, increasing acidity value in sample, and surpassing the sample value with lower concentration, implying that organic acids highest concentration is due to buriti pulp.

The results obtained for the collected samples density in the chamber oscillated between 1.24 and $1.37 \mathrm{~g} \mathrm{~cm}^{-3}$ and in the cyclone between 1.23 and $1.34 \mathrm{~g} \mathrm{~cm}^{-3}$ for each levels combination. ZAREIFARD et al. (2012) and TZE et al. (2012) found density values varying from 0.41 to $0.69 \mathrm{~g} \mathrm{~cm}^{-3}$ and from 0.29 to $0.35 \mathrm{~g} \mathrm{~cm}^{-3}$, respectively, after to study the lemon juice samples and pitaya, respectively, both with maltodextrin and dried in a spray dryer. It also was observed that powder formulations densities made with buriti pulp collected in the chamber and cyclone presented higher values, than those determined by these researchers.

According to SANTANA (2013) knowledge of the food density is important for the processing, packaging, storage and transport. Equations 7 and 8 present, the first-order coded models adjusted to the experimental data of the density as temperature function and maltodextrin concentration of the collected powder samples in the chamber and cyclone, respectively. It is observed in the Eq. 7, that densities for the collected powder in the chamber all the coded parameters were statistically significant and, in the Equation 8, for the collected powder samples in the cyclone, that only the density general average was significant.

$$
\begin{aligned}
& \text { Density }(\mathrm{Ca})=1.29-0.05 \mathrm{~T}+0.012 \mathrm{C}-0.014 \mathrm{~T} . \mathrm{C} \\
& \text { Density }(\mathrm{Ci})=1.27-0.01 \mathrm{~T}-0.002 \mathrm{C}+0.003 \mathrm{~T} . \mathrm{C}
\end{aligned}
$$

It was observed a significant effect of the drying air temperature on the density of the collected powder samples in the chamber, which suffered a decrease with increasing temperature. GOULA and ADAMOPOULOS (2010) evaluated the effect of the drying temperature on the density of the orange juice powder, which is justified by increasing temperature, which causes the evaporation rate increase and present a more porous or fragmented structure of the samples studied.

From the ANOVA results corresponding to the model adjusted of the density data of the samples collected in the chamber as temperature function and maltodextrin concentration, such results were explained by regression linear $\left(\mathrm{R}^{2}=0.9952\right)$ and $\mathrm{F}_{\text {calculated }}$ value (78.6) was higher than $\mathrm{F}_{\text {tabulated }}$ value (19.16), with a $\mathrm{F}_{\text {calculated }} / \mathrm{F}_{\text {tabulated }}$ ratio of 4.1, being this model considered statistically significant and predictive (Duarte \& Meola, 2007). Again, using ANOVA data for the model adjusted of the densities for the samples collected in the cyclone, it was verified that the $F_{\text {calculated }}(0.32)$ was smaller than the $F_{\text {tabulated }}(19.16)$, meaning that model is not statistically significant at $95 \%$ confidence and, the $\mathrm{F}_{\text {calculated }} / \mathrm{F}_{\text {tabulated }}$ ratio is lower than 4 , indicating that model is not considered predictive (DUARTE \& MEOLA, 2007). It was also observed by $\mathrm{R}^{2}$, that this equation explains only $32.59 \%$ of the total density variation, being considered a weak adjustment.

It can be seen in Figure 1(e) that the drying temperature and maltodextrin concentration show significant influences. When maltodextrin concentration passes from -1 to level +1 , density value increases with decreasing temperature; thus higher density value $\left(1.37 \mathrm{~g} \mathrm{~cm}^{-3}\right)$ was observed for the drying temperature of $130{ }^{\circ} \mathrm{C}(-1)$ and maltodextrin concentration of $15 \%(+1)$.

The response surface of the collected samples density in the cyclone not presented a statistically significant effect, since, in addition to the F-test, the linear regression was not statistically significant, and $\mathrm{R}^{2}$ was lower, aproximately 0.33 .

The better results obtained for determination of the optimum drying conditions of the buriti pulp formulations were found for the samples collected in the cyclone in the spray dryer, according to the responses studied in the factorial experimental design.

\section{Conclusions}

The first-order empirical model obtained for the density the samples collected into chamber was statistically significant and predictive. However, for titrable total acidity, model was statistically significant, but not predictive and, for the parameters of moisture content and ash, models were not statistically significant. Average of the values observed, the drying temperature, the maltodextrin concentration and interaction between these two factors showed a statistically significant effect on the density of powder samples collected in the dryer chamber. Higher density value for these samples was obtained with higher maltodextrin concentration $(15 \%)$ and lower temperature $\left(130^{\circ} \mathrm{C}\right)$. For the samples collected into chamber, the ash content was not influenced by maltodextrin concentration or temperature, or the interaction of both factors.

First-order empirical models obtained for moisture, titratable total acidity and ashes of the powder samples collected in the cyclone were statistically significant, but not predictive. For the density, models were not statistically significant. And, finally, for the ash of the samples collected in the cyclone, density parameter was not influenced by maltodextrin concentration, drying temperature or the interaction of both factors. 


\section{Acknowledgment}

This work was supported by the Federal University of Campina Grande, Campina Grande - PB; University - Masters in Environment, São Luis - MA and Coordination of higher education personnel - CAPES. Thanks to reviewers and collaborators.

\section{References}

BAG, S. K.; SRIVASTAV, P. P.; MISHRA, H. N. Optimization of process parameters for foaming of bael (Aegle marmelos L.) fruit pulp. Food Bioprocess Technology, Oxford, v. 4,(2)1450-1458, 2011.

BEZERRA, M. et al. Caprine frozen yoghurt produced with fresh and spray dried jambolan fruit pulp (Eugenia jambolana Lam.) and Bifidobacterium animalis subsp. lactis BI-07. Lwt - Food Science And Technology,62, n. 2, p.1099-1104, 2015.

CARVALHO, C. M.; FIGUEIRÊDO, R. M. F.; QUEIROZ, A. J. M.; GURJÃO, F. F. Caracterização do pó de umbucajá com leite de cabra e maltodextrina obtido pelo método de secagem em spray dryer. Tecnologia \& Ciência Agropecuária, João Pessoa,11, n.2, p.37-42, 2017.

CARVALHO, J. O.; ORLANDA, J. F. F. Heat stability and effect of $\mathrm{pH}$ on enzyme activity of polyphenol oxidase in buriti (Mauritia flexuosa Linnaeus f.) fruit extract. Food Chemistry, 233, p.159-163,2017.

CHEMAT, F. et al. Review of Green Food Processing techniques. Preservation, transformation, and extraction. Innovative Food Science \& Emerging Technologies, 41, p.357-377, 2017.

CHONG, C. H.; LAW, C. L. Drying of Exotic Fruits. In: Vegetables and Fruits v.2, Ed. Jangam, S. V., Law, C. L. and Mujumdar, A. S., Singapore, p. 1- 42, 2011.

COSTA, R. S.; OZELA, E. F.; BARBOSA, W. L. R.; PEREIRA, N. L.; SILVA JÚNIOR, J. O. C. Caracterização física, química e físico-química do extrato seco por nebulização (spray-drying) de Cynara scolymus L. (Asteraceae), Revista Brasileira de Ciências Farmacêuticas, São Paulo, v. 90, n. 3, p.169-174, 2009.

DONADIO, L. C. et al. Frutas brasileiras. Jaboticabal: Editora Novos Talentos. 248 p, 2004.

DUARTE, H. O segredo do buriti. Rio de Janeiro: Tv Globo, 2011. Disponível em: http://globoreporter.globo.com/ Globoreporter/0,19125,VVM0-2708-16149-1-0,00.html. Acesso em: 08/11/2017.

DUARTE, M. A. V.; MEOLA, T. (Coord.). Curso de Planejamento Experimental. Apostila do curso de Engenharia Mecânica da Universidade Federal de Uberlândia FEMEC. Uberlândia - MG. 2007.

GOULA, A. M.; ADAMOPOULOS, K. G. A new technique for spray drying orange juice concentrate. Innovative Food Science and Emerging Technologies, Berlin, 11, n. 2, p.342-351, 2010.

HISHIR, M. R. I.; CHEN, W. Trends of spray drying: A critical review on drying of fruit and vegetable juices. Trends In Food Science \& Technology, 65, p.49-67, 2017.

INCENZETTI, S. et al. Effects of freeze-drying and spray-drying on donkey milk volatile compounds and whey proteins stability. Lwt - Food Science And Technology, 88, p.189-195, 2018.

KOOLEN, H. H. F. et al. Antioxidant, antimicrobial activities and characterization of phenolic compounds from buriti (Mauritia flexuosa L. f.) by UPLC-ESI-MS/MS. Food Research International, 51 (2), p.467-473, 2013.

JACOB-LOPES, E.; RAMÍREZ-MÉRIDA, L. G.; MENEZES, C. R.; ZEPKA, L. Q. Microalgas: potencial para la producción de compuestos bioactivos nanoencapsulados. Ciencia e Natureza, 37, p.321-345. 2015. 
MANHÃES, L. R. T. Caracterização da polpa de buriti (Mauritia flexuosa, Mart.) com vista sua utilização como alimento funcional. 2007. 90 f. Dissertação (Mestrado em Ciência e Tecnologia de Alimentos) - Instituto de Tecnologia, Universidade Federal Rural do Rio de Janeiro, 2007.

MILANEZ, J. T. et al. Bioactive compounds and antioxidant activity of buriti fruits, during the postharvest, harvested at different ripening stages. Scientia Horticulturae, 227, p.10-21, 2018.

MURUGESAN, R.; ORSAT, V. Spray drying for the production of nutracetical ingredients - A review. Food Bioprocess Technology, 8, p.1-12, 2011.

NISTOR, O. V. et al. Influence of different drying methods on the physicochemical properties of red beetroot (Beta vulgaris L. var. Cylindra ). Food Chemistry, 236, p.59-67, 2017.

NUNES, G. L.; SILVA, T. M.; HOLKEM, A. T.; SCHLEY, V.; MENEZES, C. R. Microencapsulação de culturas probióticas: princípios do método de spray drying. Ciência e Natura, v.32, p. 121-132, 2015.

PENA, R. S.; MENDONÇA, N. B.; ALMEIDA, M. D. C. Isotermas de sorção de umidade do açaí (Euterpe oleracea) em pó. In: Congresso Brasileiro de Engenharia Química, (COBEQ), 2008, Recife. Anais... Recife: COBEQ, 2008.

PINTO, M. V. S.; SILVA, D. L.; SARAIVA, A. C. F. Obtenção e caracterização de carvão ativado de caroço de buriti (Mauritia flexuosa L. f.) para a avaliação do processo de adsorção de cobre (III). Acta Amazonica, 42, 4, 541-548, 2012.

RAY, S.; RAYCHAUDHURI, U.; CHAKRABORTY, R. An overview of encapsulation of active compounds used in food products by drying technology. Food Bioscience, 13, p.76-83, 2016.

RODRIGUES, M. I.; IEMMA, A. F. Planejamento de experimentos e otimização de processos: uma estratégia seqüencial de planejamentos.1. ed. Campinas: Casa do Pão Editora, 2005.

SAMPAIO, M. B. Manual Tecnológico de Aproveitamento Integral do Fruto e da Folha do Buriti (Mauritia flexuosa). Instituto Sociedade, População e Natureza (ISPN). Brasília - DF, 1. p.76, 2012.

SANTANA, A. A. Obtenção da polpa de pequi e do leite de coco babaçu microencapsulados através da secagem por aspersão. 2013.344 f. Tese (Doutorado em Engenharia Agrícola da Faculdade de Engenharia Agrícola) Universidade Estadual de Campinas. Campinas-SP, 2013.

SOUSA, K. S. M.; FIGUEIRÊDO, R. M. F.; QUEIROZ, A. J. M.; FERNANDES, T. K. S. Produção e caracterização da polpa de atemoia em pó. Revista Brasileira de Fruticultura. Jaboticabal - SP, 37, p. 718-728, 2015.

TZE, N. L.; HAN, C. P.; YUSOF, Y. A.; LING, C. N.; TALIB, R. A.; TAIP, F. S.; AZIZ, M. G. Physicochemical and Nutritional Properties of Spray-dried Pitaya Fruit Powder as Natural Colorant. Food Science and Biotechnology, 21, 3, p. 675-682, 2012.

ZAREIFARD, M. R.; NIAKOUSARI, M.; SHOKROLLAHI, Z.; JAVADIAN, S. A Feasibility Study on the Drying of Lime Juice: The Relationship between the Key Operating Parameters of a Small Laboratory Spray Dryer and Product Quality. Food Science and Biotechnology, 5, p. 1896-1906, 2012.

ZOTARELLI, M. F. et al. Production of mango powder by spray drying and cast-tape drying. Powder Technology, 305, p.447-454, 2017. 